\title{
Pengaruh Polimer dan Peningkat Penetrasi Terhadap Karakter Penetrasi Matriks Sediaan Patch Transdermal Karvedilol
}

\section{(Effect of Polymer and Penetration Enhancer in Matrix Penetration Character of Transdermal Patch Karvedilol)}

\author{
UNTIA KARTIKA SARI RAMADHANI ${ }^{1 *}$, JOSHITA DJAJADISASTRA ${ }^{1}$, ISKANDARSYAH ${ }^{2}$ \\ ${ }^{1}$ Departemen Pengembangan Formulasi Farmasetika, Fakultas Farmasi, \\ Universitas Indonesia, Depok, Indonesia
}

Diterima 24 Mei 2017, Disetujui 14 Juli 2017

\begin{abstract}
Abstrak: Karvedilol adalah obat anti hipertensi golongan $\beta$-blocker dengan biaovaibilitas oral yang rendah dan $\mathrm{t} 1 / 2$ yang pendek yang menyebabkan frekuensi penggunaan obat secara oral menjadi lebih sering atau dosis oral penggunaan harus ditingkatkan. Patch transdermal dengan sistem matriks mampu menghantarkan obat secara terkendali melalui kulit dalam periode waktu tertentu dan diharapkan dapat meningkatkan bioavaibilitas karvedilol dan kenyamanan bagi pasien. Penelitian ini bertujuan untuk mengetahui pengaruh polimer dan peningkat penetrasi terhadap karakter penetrasi matriks sediaan patch transdermal yang dilihat dari data kinetika pelepasan serta data penetrasi karvedilol. Ratio polimer Polivinyl Alkohol (PVA) dan Etil Selulosa (ES) serta konsentrasi peningkat penetrasi Sorbitan Monolaurat (SM) yang digunakan yaitu F1 (1:1/8\%), F2 (1:1/10\%), F3(2:1/8\%), F4(2:1/10\%). Formula F1 tidak lolos dalam evaluasi organoleptis sehingga uji selanjutnya hanya dilakukan pada formula F2, F3 dan F4. Pelepasan karvedilol secara in vitro menunjukkan formula F2, F3 dan F4 berlangsung selama 24 jam dan kinetika pelepasannya mengikuti orde 0 dan Higuchi. Uji penetrasi in vitro karvedilol menunjukkan \% kumulatif karvedilol untuk formula F2, F3 dan F4 yaitu 15,384\%, $16,495 \%$, dan $18,287 \%$.
\end{abstract}

Kata kunci: karvedilol, patch transdermal, matriks, polimer, peningkat penetrasi, uji penetrasi, kinetika pelepasan.

\begin{abstract}
Carvedilol is $\beta$-blocker antihypertensive drug with low oral bioavaibility and short half time which causes the frequency of oral drug used more often or the oral dose might be increased. Transdermal patch with the matrix system can deliver drug through skin in controlled within specific time period and hopefully it can improve carvedilol bioavaibility and convenience for patients. The aim of research was to find out the effect of polymer and penetration enhancer toward penetration characteristic of carvedilol transdermal patch matrix seen from kinetics release data and penetration data of carvedilol. The polymer ratio of Polyvinyl Alcohol (PVA):Ethyl cellulose (ES) polymers and Sorbitan Monolaurate (SM) as penetration enhancer concentrations used were F1 (1:1)/8\%, F2 (1:1)/10\%, F3 (2:1)/8\%, F4 (2:1)/10\%. Formula F1 did not pass in the organoleptictes so next test only carried out for formula F2, F3 and F4. The in vitro release of carvedilol showed formula F2, F3 and F4 lasted for 24 hours and the released kinetics of carvedilol followed the order of 0 and Higuchi. Carvedilol \% cumulative from penetration test in vitro showed for F2, F3 and F4 formulas respectively were 15,384\%, 16,495\% and 18,287\%.
\end{abstract}

Keywords: carvedilol, transdermal patch, matrix, polymer, penetration enhancer, penetration test, release kinetics.

*Penulis korespondensi: Hp :082124785840

Email: untia.ramadhani@gmail.com 


\section{PENDAHULUAN}

KARVEDILOL adalah obat anti hipertensi golongan $\beta$-blocker yang memiliki biovaibilitas oral yang terbilang rendah $(20 \%)$ dikarenakan karvedilol mengalami first past effect metabolism di hati dengan $\mathrm{t}^{1 / 2}$ yang pendek ( $\left.6 \mathrm{jam}\right)$. Hal ini menyebabkan frekuensi penggunaan karvedilol secara oral menjadi lebih sering atau dosis oral penggunaan harus ditingkatkan yang tentunya berpengaruh pada kenyamanan pasien dalam mengkonsumsi obat ${ }^{(1,2)}$.

Sistem penghantaran obat via transdermal memiliki keunggulan yang diharapkan dapat meningkatkan bioavaibilitas oral karvedilol yang rendah dan kenyamanan pasien menggunakan karvedilol. Salah satu keunggulannya ialah sistem penghantaran transdermal dapat menghindari first-pass effect yang menyebabkan jumlah obat yang mencapai sirkulasi sistemik jauh berkurang dikarenakan obat mengalami deaktivasi oleh enzim yang ada di hati karena obat dihantarkan lewat kulit selain itu sistem penghantaran transdermal dapat memberikan efek terapi yang lama dengan sekali pemakaian sehingga akan meningkatkan kenyamanan pasien bila dibandingkan dengan sediaan lainnya yang memerlukan pemberian yang sering untuk mencapai dosis terapi ${ }^{(3)}$.

Patch transdermal adalah salah satu sistem pembawa transdermal yang dapat menghantarkan obat secara terkendali melalui kulit dalam periode waktu tertentu ${ }^{(2)}$. Patch transdermal dipilih karena nyaman digunakan (noninvasif) juga diharapkan dapat memperbaiki biaovaibilitas oral karvedilol yang rendah serta mengurangi frekuensi pemberian obat karena obat dihantarkan melewati kulit dalam periode yang lama sehingga dapat meningkatkan kenyamanan pasien mengkonsumsi obat ${ }^{(2)}$.

Pada pembuatan patch transdermal, polimer merupakan komponen penyusun utama dalam pembuatan patch transdermal dengan sistem matriks. Polimer dalam sistem matriks berperan penting dalam dalam sediaan patch transdermal karvedilol sebab polimer yang bertugas mengontrol pelepasan obat dari matrik patch transdermal ${ }^{(4)}$. Kombinasi PVA dan polimer lain dapat mempengaruhi mekanisme pelepasan obat khususnya karvedilol dari $\mathrm{PVA}^{(5)}$.

Peneliti ini ingin mengetahui pengaruh kombinasi PVA dengan ES terhadap pelepasan karvedilol dimana 2 polimer yang digunakan dalam pembuatan matriks sediaan patch transdermal karvedilol memiliki perannya masing-masing yaitu etil selulosa (ES) yang membantu karvedilol larut dan berdifusi serta polivinil alkohol (PVA) yang berfungsi sebagai membran yang mengendalikan laju pelepasan karvedilol.

Peningkat penetrasi yaitu sorbitan monolaurat (span 20) digunakan untuk meningkatkan penetrasi karvedilol menembus kulit. Sorbitan monolaurat merupakan surfaktan nonionik yang dapat meningkatkan penetrasi obat lewat kulit dengan cara berpenetrasi ke daerah subkutan meningkatkan fluiditas obat yang selanjutnya melarutkan serta mengektraksi komponen lipid stratum korneum. Sorbitan monolaurat juga berikatan dengan filamen keratin yang akhirnya mengganggu korneosit sehingga obat dapat masuk ke kulit( ${ }^{(6)}$.

Penelitian yang dilakukan oleh Lopez et al pada tahun 2000 menunjukkan sorbitan monolaurat dapat meningkatkan difusivitas untuk senyawa dengan lipofiilitas yang cukup tinggi setara dengan azone ${ }^{(7)}$.

Tujuan dari penelitian ini adalah untuk mengetahui pengaruh penggunaan kombinasi polimer serta peningkat penetrasi terhadap karakter penetrasi matriks sediaan patch transdermal karvedilol yang dapat terlihat dari gambaran kinetika pelepasannya serta persen kumulatif karvedilol yang mampu menembus kulit secara in vitro.

\section{BAHAN DAN METODE}

BAHAN. Bahan-bahan yang digunakan adalah Karvedilol (CVD) (Shanxi Jinjin Chemical Co Ltd , Sigma Aldrich), Polivinil Alkohol (PVA) (Alpha Chemika), Etil Selulosa (ES) (Chemical Point), Sorbitan Monolaurate / Span 20 (TNJ), Etanol, Aqua Demineralisata, Dibuthyl phthalate (DBP) (Shandong Kexing Chem), Gliserin (Bratachem), CaCl2 (Merck), $\mathrm{KCl}$ (Merck), KH2PO4 (Merck), $\mathrm{NaOH}$ (Merck), Fase gerak HPLC, Kulit tikus putih jantan galur SpragueDawley dewasa jantan, bobot 150-200 g berumur 2-3 bulan, Plester Patch (3M).

Alat. Alat-alat yang digunakan adalah Kromatografi Cair Kinerja Tinggi (Kraneur, Jerman), kolom KCKT Zorax C-18 250 x 4,6 mm, neraca analitik (Adam AFA -210 LC, USA), Desikator, Pemanas magnetik (IKA C-MAG HS 7), desikator, Oven (Memmert, Jerman), batang pengaduk magnetik dan alat-alat gelas.

METODE. Pembuatan Matriks Sediaan Patch Transdermal Karvedilol. Patch transdermal karvedilol dibuat dengan teknik eveporasi pelarut dengan modifikasi metode pembuatan patch oleh Sonjoy, Thimmasetty, Ratan, dan Kilarimath ${ }^{(8)}$. PVA dilarutkan dalam $6 \mathrm{~mL}$ aquades yang dipanaskan pada suhu $70-80^{\circ} \mathrm{C}$ (Larutan I). Karvedilol dilarutkan dalam $9 \mathrm{~mL}$ etanol hingga larut kemudian ditambahkan etil selulosa sedikit demi sedikit hingga larut (Larutan II). Larutan II kemudian ditambahkan Span 20 hingga ketika suhu mencapai $40{ }^{\circ} \mathrm{C}$ diaduk selama 1 menit. Larutan II lalu dicampur ke larutan I yang suhunya $70{ }^{\circ} \mathrm{C}$ dengan bantuan pengaduk magnetik sedikit 
demi sedikit. Larutan polimer yang telah dicampur kemudian ditambahkan dibuthyl phtalate kemudian gliserin lalu diaduk dengan pengaduk magnetic selama 2-3 menit pada suhu $50{ }^{\circ} \mathrm{C}$. Larutan polimer-obat kemudian diletakkan pada wadah matriks film dan disimpan pada suhu ruangan selama 24 jam dan keesokan harinya di oven selama 30 menit pada suhu $40{ }^{\circ} \mathrm{C}$. Formula patch transdermal karvedilol dapat dilihat pada Tabel 1.

Visual, Organoleptis dan Kelenturan Matriks Patch Transdermal. Pengamatan visual matriks film

Tabel 1. Formula patch transdermal karvedilol.

\begin{tabular}{ccccc}
\hline Formula & F1 & F2 & F3 & F4 \\
\hline Karvedilol (mg) & 12,5 & 12,5 & 12,5 & 12,5 \\
Etil Selulosa (mg) & 150 & 150 & 100 & 100 \\
Polivinil Alkohol (mg) & 150 & 150 & 200 & 200 \\
Etanol (mL) & 6 & 6 & 6 & 6 \\
Aquades (mL) & 9 & 9 & 9 & 9 \\
Dibuthyl Phthalate (mg) & 80 & 80 & 80 & 80 \\
Gliserin (mg) & 25 & 25 & 25 & 25 \\
Span 20 (\%)b/v* & $8 \%$ & $10 \%$ & $8 \%$ & $10 \%$ \\
\hline
\end{tabular}

patch trandermal yang dilakukan meliputi warna, tekstur, bau dan kelenturan patch $^{(9)}$.

Ketebalan Matriks Patch Transdermal. Pengukuran tebal matriks film patch menggunakan alat mikrometer sekrup dan dilakukan pada 3 titik yang berbeda ${ }^{(10)}$.

Bobot Matriks Patch Transdermal. Pengujian variasi bobot matriks film patch pada setiap formula adalah dengan cara menimbang satu-persatu, kemudian dihitung bobot rata-ratanya ${ }^{(9)}$.

Kandungan Lembab Matriks Patch Transdermal. Matriks film patch yang telah disiapkan dipotong menjadi potongan dengan ukuran spesifik. Potongan patch kemudian masing-masing ditimbang dan disimpan dalam desikator yang mengandung silika pada suhu $30{ }^{\circ} \mathrm{C}$ selama 12 jam. Matriks film patch kemudian ditimbang kembali sehingga diperoleh berat yang konstan ${ }^{(11)}$.

$\%$ Kandungan lembab =

((bobot awal - bobot akhir)/(bobot akhir)) X 100\%

Persentase Daya Serap Kelembaban (Moisture Uptake) Matriks Patch Transdermal.

Matriks film patch ditimbang kemudian dimasukkan dalam desikator pada suhu $25^{\circ} \mathrm{C}$ selama 24 jam. Selanjutnya matriks film patch dikeluarkan dari desikator dan ditimbang kembali. Persen daya serap kelembaban dihitung menggunakan rumus berikut ini ${ }^{(11)}$.

$\%$ Daya serap kelembaban $=$ ((bobot akhir - bobot awal)/(bobot awal)) X 100\%

Ketahanan terhadap Pelipatan (Folding Endurance) Matriks Patch Transdermal. Uji ini dilakukan untuk mengetahui elastisitas dan kerapuhan matriks film patch transdermal. Pengujian ketahanan terhadap pelipatan dilakukan dengan melipat patch berkali-kali pada posisi yang sama sampai patch tersebut patah. Jumlah pelipatan tersebutlah yang dianggap sebagai nilai ketahanan terhadap pelipatan ${ }^{(12)}$.

Uji Laju Transmisi Uap Air (Water Vapour Tranmission Rate). Gelas vial digunakan sebagai sel transmisi. Sel transmisi (gelas vial) terlebih dahulu dicuci dan dikeringkan dalam oven. Satu gram kalsium klorida anhidrat ditempat ke dalam sel (gelas vial) dan matriks polimer diletakkan diatas di sel transmisi (gelas vial) dengan bantuan plester adhesive. Sel kemudian ditimbang dan disimpan dalam desikator yang tertutup yang mengandung larutan potasium klorida untuk menghasilkan kelembapan relatif 84\%. Sel (Vial) dikeluarkan dan ditimbang setelah $24 \mathrm{jam}^{(9)}$. Laju Transmisi Penguapan Air =

((bobot akhir- bobot awal) / waktu) X area)

Laju transmisi kecepatan transmisi dinyatakan dalam satuan gram. $\mathrm{cm}^{2} / \mathrm{jam}^{(13)}$.

Penentuan Kandungan Zat Aktif dalam Matriks Patch Transdermal. Seratus miligram karvedilol ditimbang kemudian dimasukkan ke dalam labu takar $100 \mathrm{~mL}$ kemudian dilarutkan dengan larutan metanol hingga $100 \mathrm{~mL}$ dengan bantuan sonifikasi diperoleh larutan baku standar $1000 \mu \mathrm{g} / \mathrm{mL}$ (larutan stok pertama). Larutan stok kedua dipipet $0,1 \mathrm{~mL}$ dimasukkan ke labu takar $100 \mathrm{~mL}$ sehingga diperoleh konsentrasi $100 \mu \mathrm{g} / \mathrm{mL}$ kemudian dipipet masingmasing, 1, 2, 3, 4, 5 dan $6 \mathrm{~mL}$ kemudian dimasukkan ke labu takar $10 \mathrm{~mL}$ dan ditambahkan metanol sehingga diperoleh konsentrasi $10-60 \mu \mathrm{g} / \mathrm{mL}, 13$ $\mathrm{cm}^{2}$ matriks film patch dimasukkan ke dalam $50 \mathrm{~mL}$ metanol diaduk dengan dengan magnetic bead selama 24 jam kemudian di ultrasonifikasi selama 15 menit lalu dilakukan filtrasi setelah filtrasi obat ditentukan dengan Kromatografi Cair Kinerja Tinggi.

Fase diam yang digunakan adalah kolom C-18 dengan fase gerak yang digunakan adalah $50 \mathrm{mM}$ KH2PO4, asetonitril, metanol (30:45:25 v/v/v). Volume injeksi yang diinjekkan ke KCKT adalah 40 $\mu \mathrm{L}$ dengan kecepatan alir yang digunakan $0.8 \mathrm{ml} / \mathrm{min}$ dengan panjang gelombang yang digunakan adalah $241 \mathrm{~nm}^{(12-14)}$.

Uji Transpor Karvedilol dalam Matriks Sediaan Patch Transdermal. Uji transpor dilakukan dengan menggunakan sel difusi Franz tipe vertikal yang dimodifikasi. Bagian donor berisi sediaan patch transdermal karvedilol. Membran pemisah kompartemen donor dan aseptor adalah kulit tikus. 
Membran diletakkan antara kompartemen donor dan kompartemen aseptor dengan sisi dermis menghadap kompartemen aseptor. Kompartemen aseptor berisi buffer fosfat $\mathrm{pH}$ 7,4 : metanol dengan komposisi 1:1 sebanyak $13 \mathrm{~mL}$ dan diaduk dengan pengaduk magnetik kontinu pada suhu $37^{\circ} \mathrm{C}$. Matriks film patch diletakkan diatas membran kemudian ditutup dengan alumunium foil. Pengamatan dilakukan selama 24 jam dan sampel diambil pada menit 30 dan jam ke 1, 2, $4,6,8,10,12,18,20$ dan 24 setiap kali pengambilan sampel sebanyak $3 \mathrm{~mL}$ dilakukan penambahan campuran buffer fosfat $\mathrm{pH} 7,4$ dan metanol sebanyak $3 \mathrm{~mL}$. Sampel disimpan dalam wadah flakon tertutup dan kadar karvedilol ditetapkan dengan instrumen Kromatografi Cair Kinerja Tinggi dan ditentukan jumlah karvedilol terpenetrasi, fluks pelepasan obat dan kinetika pelepasan obat ${ }^{(9,14)}$. Fase diam yang digunakan adalah kolom C-18 dengan fase gerak yang digunakan adalah $50 \mathrm{mM} \mathrm{KH}_{2} \mathrm{PO}_{4}$, asetonitril, metanol $(30: 45: 25 \mathrm{v} / \mathrm{v} / \mathrm{v})$. Volume injeksi yang diinjekkan ke KCKT adalah $40 \mu \mathrm{L}$ dengan kecepatan alir yang digunakan $0,8 \mathrm{~mL} / \mathrm{min}$ dengan panjang gelombang yang digunakan adalah $241 \mathrm{~nm}^{(12-14)}$. Rumus kumulatif jumlah bahan obat yang terpenetrasi :

Keter $Q=\frac{\left\{\text { Cn.V }+\sum_{i=1}^{n-1} C . S\right\}}{A}$

Q : Jumlah kumulatif karvedilol terpenetrasi per luas area difusi $\left(\mu \mathrm{g} / \mathrm{cm}^{2}\right)$

$\mathrm{Cn}$ : Konsentrasi rutin $(\mu \mathrm{g} / \mathrm{mL})$ pada sampling menit ke-n

$\sum_{i=1}^{n-1}$

C : Jumlah konsentrasi rutin $(\mu \mathrm{g} / \mathrm{mL})$ pada sampling pertama (menit ke-30) hingga sebelum menit ke-n

$\mathrm{V}$ : Volume sampling $(3 \mathrm{~mL})$

$\mathrm{S}$ : Luas area membrane $\left(1,77 \mathrm{~cm}^{2}\right)$

Uji Stabilitas Fisik Matriks Sediaan Patch Transdermal Karvedilol. Formula matriks patch yang optimum dilakukan uji stabilitas jangka pendek selama 4 minggu dengan menyimpan sediaan pada temperatur $4{ }^{\circ} \mathrm{C}, 40^{\circ} \mathrm{C}$ dan $60^{\circ} \mathrm{C}$ mengikuti guideline ICH Stability Testing of New Drug Substances and Products Q1A (R2). Pada tiap minggunya formula patch dikeluarkan dan dilakukan uji penampilan dan tekstur ${ }^{(12,13)}$.

\section{HASIL DAN PEMBAHASAN}

Visual, Organoleptis dan Kelenturan Matriks Patch Transdermal. Bila dilihat dari penampilan fisik, formula 1 terlihat retak dan pecah dibandingkan dengan formula 2, 3 dan 4 oleh karena itu pada ujiuji selanjutnya hanya akan dilanjutkan pada formula
F2, F3 dan F4. Berdasarkan pengamatan matriks film patch secara keseluruhan berwarna putih bening dan lentur. Tekstur film patch pada formula 3 dan 4 terasa agak kasar dikarenakan jumlah PVA yang digunakan lebih banyak bila dibandingkan dengan formula 2. Sifat lentur dan tekstur film patch juga ikut dipengaruhi oleh plastisizer yang digunakan ${ }^{(15)}$.

Ketebalan Matriks Patch Transdermal Karvedilol. Matriks film patch yang semakin tebal kurang disukai oleh penggunanya sebab dirasakan kurang nyaman digunakan ${ }^{(16)}$. Ketebalan film juga mempengaruhi permeabilitas obat menembus film dimana semakin tebal film akan menurunkan permeabilitas obat menembus film dan koefisien permeabilitas obat menembus film ${ }^{(17)}$.

Ketebalan matriks film patch transdermal karvedilol dalam penelitian ini menunjukkan formula matriks film patch (F2) memiliki ketebalan film yang lebih besar dibandingkan dengan dengan formula (F3) dan (F4). Hal ini terlihat pada data penetrasi secara in vitro dimana formula F2 yang memiliki ketebalan film yang lebih tinggi dibanding Formula F3 dan F4 justru memiliki jumlah karvedilol terpenetrasi serta \% kumulatif karvedilol terpenetrasi yang lebih rendah dibandingkan formula F3 dan F4. Ketebalan matriks patch transdermal karvedilol dapat dilihat pada Tabel 2.

Bobot Patch Transdermal Karvedilol. Bobot patch dari masing-masing formula berkisar 435-452 mg. Patch dengan bobot tertinggi adalah formula F4 yaitu formula dengan perbandingan Polivinil Alkohol : Etil Selulosa (2:1) dengan konsentrasi peningkat penetrasi Span 20 sebesar 10\%.

Kandungan Lembab Matriks Patch Transdermal Karvedilol. Kandungan lembab memiliki pengaruh terhadap penampilan fisik matriks film patch. Bila kandungan lembab terlalu sedikit akan menyebabkan patch mudah rapuh namun bila kandungan lembab terlalu tinggi maka pertumbuhan bakteri tak bisa dihindari ${ }^{(18)}$. Kandungan lembab tertinggi adalah matriks film patch formula F4. Kelembaban dapat mempengaruhi penetrasi transdermal dimana semakin tinggi kelembapan maka penetrasi transdermal juga akan meningkat ${ }^{(19)}$. Hal ini

Tabel 2. Ketebalan matriks film patch transdermal karvedilol.

\begin{tabular}{ll}
\hline Formula & Ketebalan \pm SD \\
\hline F2 & $0.123 \pm 0.016$ \\
F3 & $0.113 \pm 0.009$ \\
F4 & $0.118 \pm 0.015$ \\
\hline
\end{tabular}


ditunjukkan juga pada data penetrasi dimana formula F4 (kadar lembab paling tinggi) memiliki \% kumulatif karvedilol terpenetrasi lebih tinggi dibandingkan formula F2 dan F3 (Tabel 3).

Daya Serap Kelembapan (Moisture Uptake). Daya serap kelembapan (moisture uptake) menggambarkan kemampuan menyerap kembali kelembapan dari lingkungan sekitar. Pengukuran daya serap kelembapan memberikan gambaran awal terhadap stabilitas patch selama penyimpanan ${ }^{(16,18)}$. Formula F3 dan F4 dengan perbandingan polivinil alkohol : etil selulosa (2:1) memilki daya serap kelembapan lebih tinggi dibandingkan dengan F2 dengan perbandingan polivinil alkohol : etil selulosa (1:1). Konsentrasi peningkat penetrasi span 20 juga ikut mempengaruhi daya serap kelembapan patch dimana pada formula 3 dan 4 dengan komposisi polivinil alkohol : etil selulosa yang sama (2:1), daya serap kelembapan formula formula $\mathrm{F} 4$ dengan konsentrasi peningkat penetrasi span $20(10 \%)$ lebih besar dibandingkan F3 (Span 20 8\%) (Tabel 4).

Ketahanan Terhadap Pelipatan Matriks Patch Transdermal Karvedilol. Ketahanan terhadap pelipatan adalah parameter untuk melihat fleksibilitas matriks film dan kekuatan dari matriks film patch mudah untuk sobek atau tidak. Tabel 5 menunjukkan formula F2 dengan komposisi PVA : ES (1:1) memiliki ketahanan pelipatan yang lebih baik dibandingkan formula F3 dan F4 (2:1). Komposisi PVA mempengaruhi ketahanan matriks film terhadap pelipatan.

Uji Laju Transmisi Uap Air. Laju transmisi uap air adalah hilangnya kandungan air/lembab yang ditransmisikan per unit waktu melalui film dalam setiap jamnya, dinyatakan dalam satuan g/ $\mathrm{jam} / \mathrm{cm}^{2}$. Uji laju transmisi uap air dilakukan untuk mengukur dengan kemampuan permeabilitas film patch karvedilol terhadap penguapan air ${ }^{(20)}$. Formula F2 memiliki uji laju transmisi uap yang lebih cepat dibandingkan Formula F3 dan F4 walau tidak berbeda signifikan (Tabel 6).

Nilai laju tranmisi uap air berbanding terbalik dengan kandungan lembab dimana semakin lambat laju film melepaskan uap air maka akan semakin besar kandungan lembab yang terkandung di film patch transdermal ${ }^{(21)}$.

Penentuan Kandungan Patch Transdermal Karvedilol. Penentuan kandungan karvedilol dalam sediaan matriks patch transdermal dilakukan dengan menggunakan kromatografi cair kinerja tinggi. Kadar matriks patch yang diperoleh berkisar 90,37697,747\% (Tabel 7).

Uji Penetrasi Secara In Vitro Patch Transdermal Karvedilol. Sediaan yang akan diuji penetrasinya
Tabel 3. Persen kumulatif karvedilol yang terpenetrasi setelah 24 jam. Formula \% Rata-Rata Kumulatif

\begin{tabular}{ll}
\hline F2 & 15,384 \\
F3 & 16,495 \\
F4 & 18,287
\end{tabular}

Keterangan : Buffer Fosfat $\mathrm{pH} 7,4:$ Metanol (1:1) $\mathrm{v} / \mathrm{v}$ Keterangan: F2 =PVA: ES (1:1)/ Span $20(10 \%)$;

F3 = PVA : ES ( 2:1) / Span 20 (8\%); F4=PVA: ES (2:1)/ Span 20 (10\%)

Tabel 4. Daya serap kelembaban (moisture uptake).

\begin{tabular}{ll}
\hline Formula & Moisture Uptake \\
\hline F2 & $1.83 \pm 0.22$ \\
F3 & $4.09 \pm 2.32$ \\
F4 & $5.65 \pm 1.99$ \\
\hline
\end{tabular}

Tabel 5. Ketahanan pelipatan matriks film patch transdermal karvedilol.

\begin{tabular}{cc}
\hline Formula & Ketahanan Pelipatan \\
\hline F2 & $165 \pm 3.00$ \\
F3 & $125,67 \pm 5.13$ \\
F4 & $76,67 \pm 7.67$ \\
\hline
\end{tabular}

Tabel 6. Uji laju transmisi uap.

\begin{tabular}{|c|c|c|}
\hline Formula & $\begin{array}{c}\text { Uji Laju Transminis Lap } \\
\text { (gram/jam/(min') }\end{array}$ & $\begin{array}{c}\text { Kandungan Lembalo } \\
(\%)\end{array}$ \\
\hline $\mathrm{F} 2$ & $0,1111+0,0014$ & $0,553+0.143$ \\
\hline $\mathrm{F} 3$ & $0,1098+0,0029$ & $1,145+0.391$ \\
\hline $\mathrm{F} 4$ & $0,1055+0,0023$ & $2,624+0.549$ \\
\hline
\end{tabular}

Tabel 7. Kadar karvedilol dalam matriks patch transdermal karvedilol.

\begin{tabular}{cc}
\hline Formula & Kadar karvedilol (\%) \\
\hline F2 & $90,376+0.149$ \\
F3 & $97,747+0.017$ \\
F4 & $96,333+0.066$ \\
\hline
\end{tabular}

adalah sediaan patch karvedilol dalam bentuk film. Uji penetrasi secara in vitro patch karvedilol dilakukan dengan menggunakan sel difusi Franz. Pengujian dilakukan untuk mengetahui jumlah karvedilol yang dapat berpenetrasi melalui kulit selama interval waktu tertentu, fluks obat yang berpenetrasi dan kinetika pelepasan obat. Penetrasi selama 24 jam 
dilakukan dengan 2 jenis medium yaitu buffer fosfat pH 7,4 : metanol dengan komposisi (1:1) v/v. Jumlah karvedilol yang diperoleh untuk penetrasi sediaan patch karvedilol selama 24 jam dengan medium buffer fosfat $\mathrm{pH} 7,4:$ metanol $(1: 1) \mathrm{v} / \mathrm{v}$ masing- masing dari F2, F3 dan F4 adalah $30,830 \mu \mathrm{g} / \mathrm{cm}^{2}, 36,903 \mu \mathrm{g} / \mathrm{cm}^{2}$ dan $37.889 \mu \mathrm{g} / \mathrm{cm}^{2}$.

Jumlah karvedilol yang terpenetrasi dan \% kumulatif optimum diperoleh ketika komposisi PVA : ES yang digunakan adalah 2:1 (F4). Hal ini disebabkan formula yang menggunakan polimer hidrofilik (PVA) dengan komposisi lebih banyak akan meningkatkan hidrasi matriks polimer sehingga memudahkan proses swelling dengan lebih baik ${ }^{(22)}$.

Proses swelling yang optimum akan memudahkan obat untuk larut atau terdispersi dalam matriks yang selanjutnya akan membuat obat lebih banyak yang keluar dari matriks dengan cara berdifusi namun tetap terkendali laju pelepasannya. Sifat mengembang polimer hidrofilik seperti polivinil alkohol akan membentuk lapisan gel yang akan mengontrol pelepasan obat. Formulasi matriks yang menggunakan polimer hidrofilik dan lipofilik, pelepasan obat sangat dipengaruhi oleh disolusi obat yang selanjutnya obat yang larut baru dapat keluar dari jaringan pori polimer ${ }^{(23)}$.

Persen kumulatif karvedilol yang berpenetrasi juga ikut meningkat seiring dengan konsentrasi Span 20 yang meningkat, hal ini terlihat pada F3 dan F4 yang sama-sama memiliki komposisi PVA : ES (2:1), jumlah karvedilol yang berpenetrasi pada F4 (Span 20 konsentrasi 10\%) lebih besar dibandingkan F3 (Span 20 konsentrasi 8\%). Polivinil alkohol merupakan polimer yang memiliki pori dimana kecepatan hidrasinya meningkat ketika ditambahkan surfaktan nonionik dengan mekanisme mengembang dan difusi sehingga jumlah karvedilol yang dilepaskan lebih banyak ketika konsentrasi Span 20 yang digunakan semakin tinggi ${ }^{(5)}$.

Formula F2, F3 dan F4 mencapai kondisi steady state pada jam ke-10 hingga jam ke-24 (Gambar 4). Gradien konsentrasi merupakan suatu gaya dorong (driving force) bagi suatu zat aktif untuk melewati membran secara difusi pasif. Setelah mencapai keadaan masa tunak, fluks tidak lagi dipengaruhi oleh gradien konsentrasi atau ketebalan membran dan bentuk kurva menjadi datar ${ }^{(24)}$. Gambar 4 dapat diamati bahwa setelah jam ke-10 bentuk grafik agak datar dimana kondisi steady state mulai berlangsung. Hal ini juga menunjukkan kecepatan permeasi obat sudah mulai konstan.

Kinetika pelepasan patch transdermal karvedilol juga ditetapkan dari uji difusi franz berdasarkan persen kumulatif karvedilol yang terpenetrasi. Sediaan transdermal seperti patch karvedilol pada umumnya mengikuti kinetika orde 0 dimana kecepatan pelepasan obat konstan selama periode waktu tanpa dipengaruhi oleh waktu. Gambar 5 menunjukkan bahwa formula F2, F3 dan F4 mengikuti kinetika pelepasan orde 0 dengan formula yang paling mendekati kinetika orde 0 adalah $\mathrm{F} 3(\mathrm{r}=0,9803)$.

Model Higuchi adalah kinetika pelepasan yang dapat menggambarkan pelepasan obat dalam sistem matriks. Patch transdermal karvedilol dibuat sistem matriks maka ditetapkan pula kinetika pelepasan Patch karvedilol mengikuti model Higuchi. Gambar 6 menunjukkan bahwa formula F2, F3 dan F4 juga mengikuti kinetika pelepasan model Higuchi dengan formula yang paling mendekati kinetika model Higuchi adalah F2 $(r=0,9890)$.

Uji Stabilitas Fisik Sediaan Patch Transdermal Karvedilol. Uji stabilitas fisik sediaan patch karvedilol meliputi warna, tekstur, bau dan kelenturan. Uji stabilitas fisik sediaan dilakukan selama 4 minggu

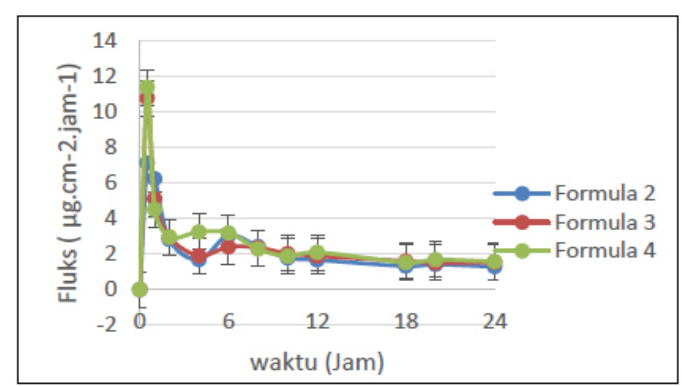

Gambar 4. Grafik fluks patch karvedilol dengan buffer fosfat pH 7,4: metanol (1:1) v/v.

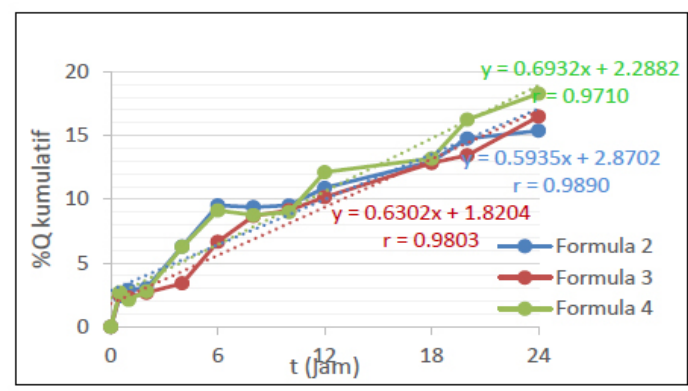

Gambar 5. Grafik kinetika pelepasan orde 0 patch transdermal karvedilol.

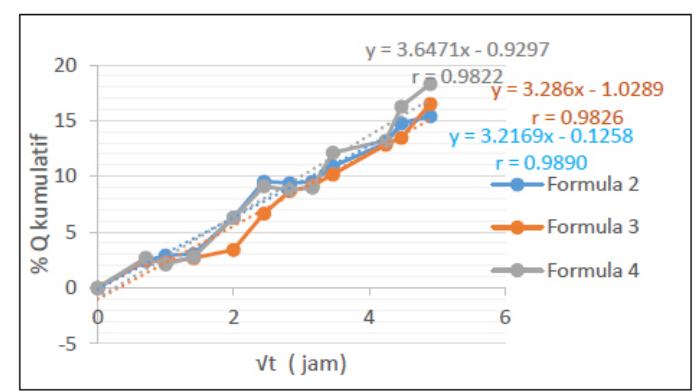

Gambar 5. Grafik kinetika pelepasan model Higuchi patch transdermal karvedilol. 
pada suhu $4{ }^{\circ} \mathrm{C}, 40{ }^{\circ} \mathrm{C}$ dan $60^{\circ} \mathrm{C}$. Matriks film patch transdermal karvedilol yang disimpan pada suhu $4{ }^{\circ} \mathrm{C}$ selama 4 minggu lebih stabil dibanding dengan patch karvedilol yang disimpan pada suhu $40^{\circ} \mathrm{C}$ dan $60^{\circ} \mathrm{C}$ selama 4 minggu. Hal ini dikarenakan tidak terjadi perubahan penampilan fisik sebelum dan sesudah film patch karvedilol disimpan pada suhu $4{ }^{\circ} \mathrm{C}$. Matriks film patch karvedilol yang disimpan pada suhu $45^{\circ} \mathrm{C}$ dan $60^{\circ} \mathrm{C}$ selama 4 minggu tidak stabil karena terjadi perubahan penampilan fisik baik dari warna maupun tekstur setelah 4 minggu penyimpanan.

Penyimpanan matriks film patch pada suhu $40{ }^{\circ} \mathrm{C}$ selama 4 minggu menyebabkan terjadinya perubahan tekstur namun tidak mengalami perubahan warna pada film patch sedangkan pada suhu $60^{\circ} \mathrm{C}$ menyebabkan matriks film patch mengalami perubahan tekstur dan warna. Hal ini dikarenakan PVA mulai mengalami dekomposisi pada $30-40{ }^{\circ} \mathrm{C}$ ketika disimpan dalam waktu yang lama. Dekomposisi pada suhu yang lebih tinggi dapat menyebabkan terjadinya perubahan warna yaitu dari kuning hingga hitam ${ }^{(25)}$. Etil selulosa juga mulai mengalami degradasi ketika disimpan pada suhu melebihi $32{ }^{\circ} \mathrm{C}$ dalam jangka waktu yang lama ${ }^{(26)}$.

\section{SIMPULAN}

Pelepasan karvedilol secara in vitro dari formula F2, F3 dan F4 matriks patch transdermal karvedilol berlangsung selama 24 jam mengikuti orde 0 dan Higuchi. Formula optimum matriks patch karvedilol yang mengikuti orde 0 dan Higuchi adalah formula F3 dengan $r$ untuk orde $0=0,9803$ dan formula F2 dengan $r$ untuk model Higuchi $=0,9890$. Data penetrasi diperoleh persen kumulatif karvedilol yang terpenetrasi dengan menggunakan Span 20 sebagai peningkat penetrasi untuk masing-masing untuk F2, F3 dan F4 adalah 15.384\%, 16.495\% dan $18.287 \%$. Hal ini menunjukkan terdapat peranan polimer yaitu polivinil alkohol dan etil selulosa yang mengatur kinetika pelepasan obat sehingga kinetika pelepasannya mengikuti orde 0 maupun model Higuchi walau Span 20 belum optimal dalam meningkatkan penetrasi karvedilol sehingga persen kumulatif karvedilol yg terpenetrasi masih rendah.

\section{DAFTAR PUSTAKA}

1. Sweetman SC. Martindale: the complete drug reference. Pharmaceutical press; 2009.

2. Ubaidulla U, Reddy M V, Ruckmani K, Ahmad F J, \& Khar R K. Transdermal therapeutic system of carvedilol: effect of hydrophilic and hydrophobic matrix on in vitro and in vivo characteristics. AAPS Pharm Sci Tech. 2007. 8(1): E13-E20.
3. Allen L, \& Ansel H C. Ansel's pharmaceutical dosage forms and drug delivery systems. Philadhelpia: Lippincott Williams \& Wilkins; 2013. 295.

4. Sharma K, Singh V, \& Arora A. Natural biodegradable polymers as matrices in transdermal drug delivery. International Journal of Drug Development \& Research. 2011. 3(2): 85-103.

5. Wise D L. Handbook of pharmaceutical controlled release technology. New York: Marcell Dekker; 2000.

6. Pandey A, Mittal A, Chauhan N, \& Alam S. Role of surfactants as penetration enhancer in transdermal drug delivery system. J Mol Pharm Org Process Res. 2014. 2(113).

7. López A F C M, Llinares F, Cortell C, \& Herraez M. Comparative enhancer effects of Span ${ }^{\circledR} 20$ with Tween ${ }^{\circledR} 20$ and Azone ${ }^{\circledR}$ on the in vitro percutaneous penetration of compounds with different lipophilicities. International journal of pharmaceutics. 2000. 202(1): 133-140.

8. Sonjoy M, Thimmasetty J, Ratan G N, \& Kilarimath B H. Formulation and evaluation of carvedilol transdermal patches. Int Res JPharm. 2011. 2(1): 237-48.

9. Mounika K, Reddy B K, Reddy K N. Formulation and evaluation of carvedilol transdermal patches with hydrophilic polymers. World Journal of Pharmaceutical Research. 2014. 3(10).

10. Su G, Cai H, Zhou C, \& Wang Z. Formation of edible soybean and soybean-complex protein films by a cross-linking treatment with a new Streptomyces transglutaminase. Food Technology \& Biotechnology. 2007. 45(4).

11. Kharjul, et al. Formulation, characterization and evaluation (in vivo in vitro study of matrix type transdermal patches of carvedilol). International Journal Of Research In Pharmacy And Chemistry. 2012. 2(3): 830.

12. Nandy, et al. Effect of various polymers on carvedilol transdermal films: in- vitro permeation studies. Pelagia Research Library Der Pharmacia Sinica. 2011. 2 (4):203-17.

13. Dey S, \& Malgope A. Preparation of carvedilol transdermal patch and the effect of propylene glycol on permeation. International Journal of Pharmacy and Pharmaceutical Sciences. 2010. 2: 137-43.

14. Ketema G, \& Sankar D G. RP-HPLC method for estimation of carvedilol in pharmaceutical dosage forms. Am J Pharm Tech Res. 2012. 2: 513-21.

15. Madhulatha A, \& Naga Ravikiran T. Formulation and evaluation of ibuprofen transdermal patches. International Journal of Research in Pharmaceutical and Biomedical Sciences. 2013. 4(1): 351-62.

16. Indrati $\mathrm{O}$, Nugroho A. Pengaruh asam oleat, propilen glikol dan isopropil alkohol pada formula patch transdermal kalium losartan dengan matriks hidroksipropil metilselulosa dan etil selulosa [disertasi]. Yogyakarta: Fakultas Farmasi Universitas Gadjah Mada. 2012.

17. Bernal-Ballén A, Kuritka I, \& Saha P. Preparation and 
characterization of a bioartificial polymeric material: bilayer of cellulose acetate-PVA. International Journal of Polymer Science. 2016.

18. Mukherjee B, Kanupriya M S, Das S, \& Patra B. Sorbitan monolaurate 20 as a potential skin permeation enhancer in transdermal patches. J Appl Res. 2005. 1: $96-108$.

19. Saxena J. Hazard assessment of chemicals: current developments. Elsevier; 2013.

20. Bharkatiya M, Nema R K, \& Bhatnagar M. Designing and characterization of drug free patches for transdermal application. International Journal of Pharmaceutical Sciences and drug research. 2010. 2(1): 35-9.

21. Smith E W, \& Maibach H I. Percutaneous penetration enhancers. London: CRC Press; 2005.

22. Yoo Y, Shin H W, \& Nam B G. Effect of hydrophiliclipophilic balance of drugs on their release behavior from amphiphilic matrix. Macromolecular research. 2003. 11(4): 283-90.

23. Ali T, Shoaib M H, Yousuf R I, Jabeen S, Muhammad I N, \& Tariq A. Use of hydrophilic and hydrophobic polymers for the development of controlled release tizanidine matrix tablets. Brazilian Journal of Pharmaceutical Sciences. 2014. 50(4): 799-818.

24. Sinko P J, Allen Jr L V, Popovich N G, \& Ansel H C. Martin's Physical Pharmacy and Pharmaceutical Sciences. 2006.

25. Taghizadeh M. Thermal degradation behavior of polyvinyl alcohol/starch/carboxymethyl cellulose/ clay nanocomposites. Universal Journal of Chemistry. 2013. 1(2): 21-9.

26. Rowe R C. Handbook of pharmaceutical excipients. London: Pharmaceutical Press; 2010. 